\title{
SELECTIVE GLAZE FOR LAST LINE VISIBLE THERMAL HEAD
}

\author{
KAORU HASHIMOTO ${ }^{\dagger}$, NOBUO KAMEHARA $\dagger$, MINORU TERASHIMA $\ddagger$ \\ and KOICHI NIWA ${ }^{\dagger}$ \\ $\dagger$ Fujitsu Laboratories Ltd.; $¥$ Fujitsu Limited \\ 1015 Kamikodanaka, Nakahara-ku, Kawasaki, 211 Japan
}

\begin{abstract}
A thermal head in which the last line is visible allows characters to be viewed as soon as they are printed. The thermal head is constructed with a selective glazed layer and heat sources, which are formed at the edge of a ceramic substrate. The selective glazed layer must be smooth and flat, even at the edge, for heat sources to be formed on it. Selective glaze characteristics were studied using $\mathrm{PbO}-\mathrm{B}_{2} \mathrm{O}_{3}-\mathrm{SiO}_{2}$ and $\mathrm{B}_{2} \mathrm{O}_{3}-\mathrm{SiO}_{2}$ glazing materials to realize the last line visible thermal head. Several commercially available gold conductors were screen printed on fine grained alumina substrates. Wettability, levelling characteristics and flatness at the edge of the selective glaze on each gold conductor were examined. Dependence of their characteristics on firing conditions were also examined. A combination of $\mathrm{PbO}-\mathrm{B}_{2} \mathrm{O}_{3}-\mathrm{SiO}_{2}$ glass and fritless gold conductor provides a smooth and flat glaze surface even at the edge, and experimental results show that $\mathrm{PbO}-\mathrm{B}_{2} \mathrm{O}_{3}-\mathrm{SiO}_{2}$ glazing material has the most suitable characteristics for a last line visible thermal head. A last line visible thermal head was formed using $\mathrm{PbO}-\mathrm{B}_{2} \mathrm{O}_{3}-\mathrm{SiO}_{2}$ glazing material. The selective glazed layer was formed over the thick film circuits of gold for the power supply, which were screen printed on a fine grained alumina substrate. $\mathrm{Ta}_{2} \mathrm{~N}$ thin film for resistive heat sources was formed at the edge of the glazed layer. The thermal head provides good print quality and can print 20 characters/line at 5 lines/sec with a resolution of $2.7 \mathrm{dots} / \mathrm{mm}$.
\end{abstract}

\section{INTRODUCTION}

Thermal heads are now being used more and more in the non-impact printers because of their high reliability and noise-free operation. These heads are generally constructed with a selective glazed layer formed on a ceramic substrate, with resistive heat sources at the edge. The selective glazed layer has low thermal conductivity and helps maintain the heat for thermal printing which is generated by applying power to the resistors formed on the glazed layer. Smoothness and flatness of the glazed layer affect dimensional accuracy of the resistor pattern and the uniformity of resistivity. It is necessary, therefore, that the selective glazed layer be smooth and flat. If the surface can be made smooth and flat even at the edge, it becomes possible to form resistive heat sources there, allowing the characters to be seen as soon as they are printed. This type of thermal head is called a "last line visible thermal head". It is not possible to realize this head unless the selective glazed layer is flat and smooth, even at the edge. The ridge which is normally generated at the edge of the selective glazed layer makes it difficult to obtain the uniform resistivity of heat sources needed for good print quality at the edge.
During the glazing process, the glazing material softens and flows, forming a ridge at the edge because of surface tension of the glazing material. Inadequate wettability between the glazing and conductor materials for the power supply circuits under the glazed layer produces an uneven glaze surface. Surface tension and wettability depend on the properties of the glazing and conductor materials themselves. Surface tension could be reduced by providing adequate wettability between the glazing and conductor materials, resulting in a smooth and flat glaze surface even at the edge. To that end, it is intended to study glazing and conductor materials from the viewpoint of wettability.

In this experiment, selective glaze characteristics were studied using $\mathrm{PbO}-\mathrm{B}_{2} \mathrm{O}_{3}-\mathrm{SiO}_{2}$ and $\mathrm{B}_{2} \mathrm{O}_{3}-\mathrm{SiO}$ ? glazing materials. Wettability, levelling characteristics and flatness of the glazed layer on several commercially available gold conductors were examined. Dependence of their characteristics on firing conditions were also examined. As a last step, the last line visible thermal head was produced using glazing and conductor materials of adequate wettability. 


\section{EXPERIMENTAL PROCEDURE}

The last line visible thermal head consists of a ceramic substrate, conductor patterns, the selective glazed layer and resistive heat sources as shown in Figure 1. The selective glazed layer and resistive heat sources are formed at the edge of the head. Characteristics of the selective glaze at the edge are especially important because that is where the resistive heat sources are formed.

Several glazing materials were first examined on ceramic substrates to obtain the smoothest surface. They were then evaluated, according to wettability, on various conductors.

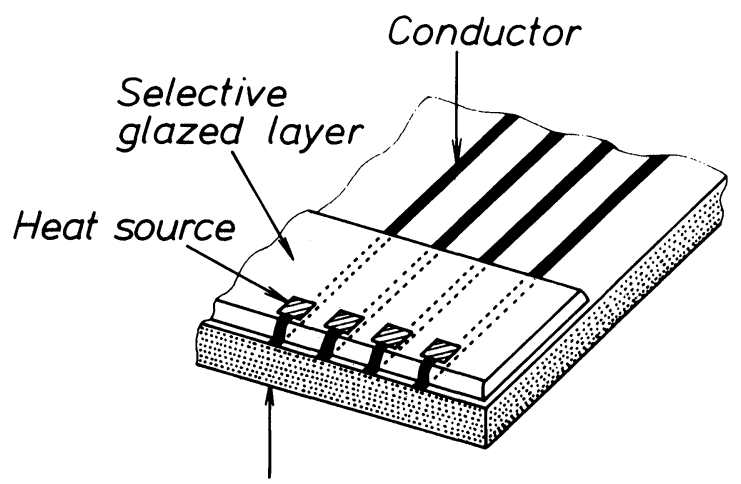

Ceramic substrate

FIGURE 1 Schematic illustration of last line visible thermal head.

\subsection{Glaze on Substrate}

The glazing materials used in this experiment were $\mathrm{PbO}-\mathrm{B}_{2} \mathrm{O}_{3}-\mathrm{SiO}_{2}$ glass and two types of $\mathrm{B}_{2} \mathrm{O}_{3}-\mathrm{SiO}_{2}$ glasses, whose compositions are shown in Table $\mathrm{I}$. Using these glasses as the starting powders, glazing pastes were prepared by mortar ground with ethylcellulose and terpineol. The glazing pastes were screen printed on fine grained alumina substrates ${ }^{1,2}$ using a 200 mesh nylon screen. The glazed layers were formed by firing for $10 \mathrm{~min}$ at various temperatures between 800 and $1250^{\circ} \mathrm{C}$.

Surface roughness of the glazed layer was measured

TABLE I

Composition of glazing materials used for evaluation.

\begin{tabular}{llccc}
\hline & \multicolumn{3}{c}{ Composition (wt\%) } \\
\cline { 2 - 5 } Glazing material & $\mathrm{PbO}$ & $\mathrm{B}_{2} \mathrm{O}_{3}$ & $\mathrm{SiO}_{2}$ & $\mathrm{Al}_{2} \mathrm{O}_{3}$ \\
\hline $\mathrm{PbO} \mathrm{B}_{2} \mathrm{O}_{3}-\mathrm{SiO}_{2}$ & 54.5 & 7.5 & 28.0 & 10.0 \\
$\mathrm{~B}_{2} \mathrm{O}_{3}-\mathrm{SiO}_{2}(\mathrm{I})$ & - & 28.0 & 71.0 & 1.0 \\
$\mathrm{~B}_{2} \mathrm{O}_{3}-\mathrm{SiO}_{2}$ (II) & - & 23.0 & 70.0 & 7.0 \\
\hline
\end{tabular}

using the Taly step stylus method to determine the center line average surface roughness $\left(R_{\mathrm{CLA}}\right)$. Maximum height of the stylus trace was measured to determine warpage of the substrate with glazed layer. Surface defects were examined using an optical microscope, and imperfections in the thin film patterns deposited on the glazed layer were also examined.

\subsection{Glaze on Conductor}

The commercially available gold conductor pastes listed in Table II were used for evaluating wettability with the glazing material. Conductor pastes were screen printed on fine grained alumina substrates to form $200 \mu \mathrm{m}$ wide conductor patterns spaced $160 \mu \mathrm{m}$ apart. After metallizing the conductor patterns at $900^{\circ} \mathrm{C}$ for $10 \mathrm{~min}$ glazing pastes were screen printed on the conductor patterns and fired at $860^{\circ} \mathrm{C}$ for $10 \mathrm{~min}$.

Flatness and surface roughness at the edge of the glazed layer overlying conductor patterns were measured using the Taly step stylus method. Flatness was evaluated by two factors: edge height $(\Delta h)$ and edge length $(\Delta l)$ which are defined in Figure 2 . Wettability of

$\Delta h:$ Edge height
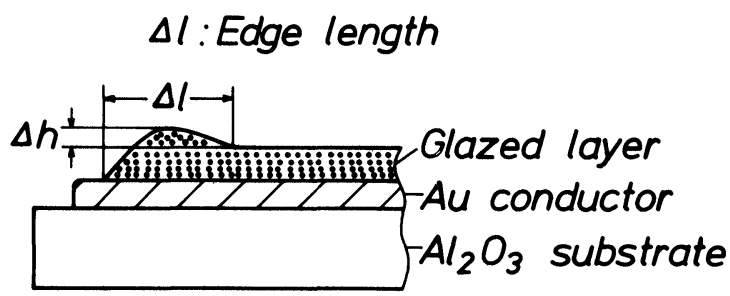

FIGURE 2 Definition of edge height $(\Delta h)$ and edge length $(\Delta l)$.

TABLE II

Gold conductor pastes used for evaluation.

\begin{tabular}{lll}
\hline Conductor paste & Code No. & Supplier \\
\hline G-1 & ESL 8835-1B & Electro-Science Laboratories, Inc. \\
G-2 & DP 8760 & E.I. du Pont de Nemours \& Co. \\
G-3 & DP 9791 & E.I. du Pont de Nemours \& Co. \\
G-4 & EO 6975S & Electro Oxide Co. \\
\hline
\end{tabular}


the glazing material with the conductor material was examined by optical microscope, observing the flow of the glazed layer on the conductor patterns.

\section{RESULTS AND DISCUSSION}

\subsection{Glaze on Substrate}

The changes in surface roughness of the glazed layer with firing temperature are shown in Figure 3.

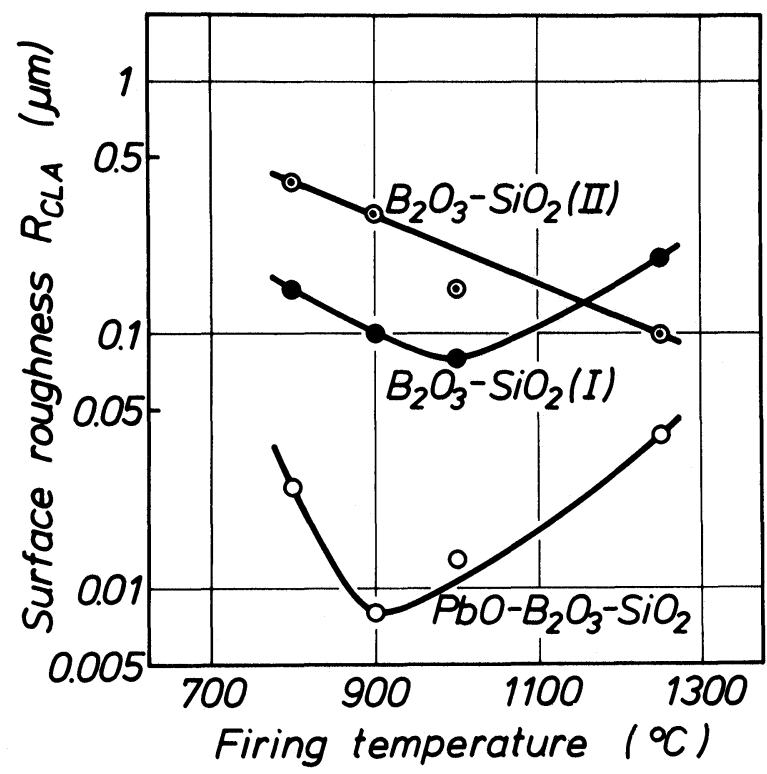

FIGURE 3 Effect of firing temperature on surface roughness of glazed layer.

$\mathrm{PbO}-\mathrm{B}_{2} \mathrm{O}_{3}-\mathrm{SiO}_{2}$ glass shows a smoother surface than $\mathrm{B}_{2} \mathrm{O}_{3}-\mathrm{SiO}_{2}$ glasses over the entire firing temperature range. $\mathrm{PbO}-\mathrm{B}_{2} \mathrm{O}_{3}-\mathrm{SiO}_{2}$ glass shows a minimum surface roughness of $0.008 \mu \mathrm{m}$ at $900^{\circ} \mathrm{C} . \mathrm{B}_{2} \mathrm{O}_{3}-\mathrm{SiO}_{2}$ glass (I) fired at $1000^{\circ} \mathrm{C}$ shows $0.08 \mu \mathrm{m}$ of surface roughness, which is ten times larger than that of $\mathrm{PbO}-\mathrm{B}_{2} \mathrm{O}_{3}-\mathrm{SiO}_{2}$ glass. The surface defects shown in Figure 4 are produced on the glazed surface layer formed by $\mathrm{B}_{2} \mathrm{O}_{3}-\mathrm{SiO}_{2}$ glass.

Alumina substrates will warp during cooling from high glazing temperatures if the thermal expansion coefficient differs between the glazing material and substrate. $\mathrm{B}_{2} \mathrm{O}_{3}-\mathrm{SiO}_{2}$ glass causes the alumina substrate to warp because of the thermal expansion mismatch. $\mathrm{PbO}-\mathrm{B}_{2} \mathrm{O}_{3} \mathrm{SiO}_{2}$ glass, however, does not warp the substrate, which indicates that $\mathrm{PbO}-\mathrm{B}_{2} \mathrm{O}_{3}-\mathrm{SiO}_{2}$ glass has

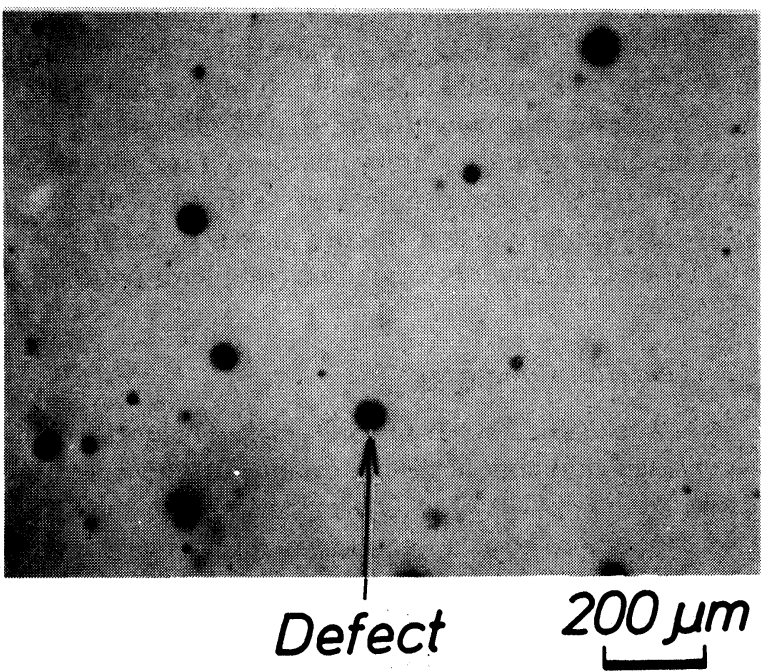

FIGURE 4 Surface defects formed on $\mathrm{B}_{2} \mathrm{O}_{3}-\mathrm{SiO}_{2}$ glazed layer.

approximately the same thermal expansion coefficient as the alumina substrate.

These results show that with $\mathrm{PbO}-\mathrm{B}_{2} \mathrm{O}_{3}-\mathrm{SiO}_{2}$ glass, a smooth glazed surface without defects or warpage of the alumina substrate can be produced. Surface roughness of the glazed layer is closely related to imperfections in the thin film patterns formed on the glazed layer, as shown in Figure 5. Imperfection in the

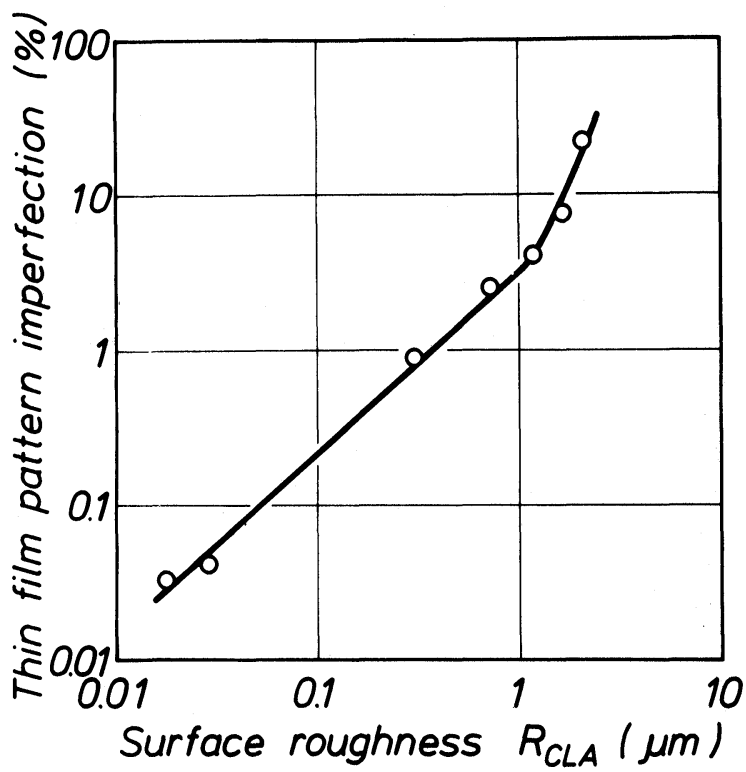

FIGURE 5 Relation between thin film pattern imperfection and surface roughness of glazed layer. 
thin film patterns decreases when the patterns are formed on the $\mathrm{PbO}-\mathrm{B}_{2} \mathrm{O}_{3}-\mathrm{SiO}_{2}$ glazed layer. Elimination of warpage also makes it possible to obtain fine and dense circuit patterns with $\mathrm{PbO}-\mathrm{B}_{2} \mathrm{O}_{3}-\mathrm{SiO}_{2}$ glass, because dimensional accuracy increases if the substrate does not warp. These results suggest that $\mathrm{PbO}-\mathrm{B}_{2} \mathrm{O}_{3}$ $\mathrm{SiO}_{2}$ glass can produce a smooth glazed surface, even when the glazed layer is formed on conductor patterns.

\subsection{Glaze on Conductor}

Characteristics of $\mathrm{PbO}-\mathrm{B}_{2} \mathrm{O}_{3}-\mathrm{SiO}_{2}$ glazed layers formed on various gold conductor materials are shown in Table III. A PbO- $\mathrm{B}_{2} \mathrm{O}_{3}-\mathrm{SiO}_{2}$ glazed layer on the G-1 gold conductor shows a flat surface at the edge with an edge height of $6.0 \mu \mathrm{m}$ and an edge length of $0.50 \mathrm{~mm}$, this layer provides the lowest values among the conductor materials in Table III. Adequate wettability of $\mathrm{PbO}-\mathrm{B}_{2} \mathrm{O}_{3}-\mathrm{SiO}_{2}$ glass with the $\mathrm{G}-1$ conductor is considered to be the reason those low values can be attained.

TABLE III

Edge height and edge length for $\mathrm{PbO}-\mathrm{B}_{2} \mathrm{O}_{3}-\mathrm{SiO}_{2}$ glazed layer formed on various conductors.

\begin{tabular}{lll}
\hline Conductor paste & $\begin{array}{l}\text { Edge height } \\
\Delta h(\mu \mathrm{m})\end{array}$ & $\begin{array}{l}\text { Edge length } \\
\Delta l(\mathrm{~mm})\end{array}$ \\
\hline G-1 & 6.0 & 0.50 \\
G-2 & 14.0 & 0.62 \\
G-3 & 12.3 & 0.78 \\
G-4 & 15.5 & 0.95 \\
\hline
\end{tabular}

Wettability of $\mathrm{PbO}-\mathrm{B}_{2} \mathrm{O}_{3}-\mathrm{SiO}_{2}$ glass with gold conductor materials greatly affects flatness and configuration of the glazed layer at the edge. As $\mathrm{PbO}-\mathrm{B}_{2} \mathrm{O}_{3}-\mathrm{SiO}_{2}$ glass has excess wettability with the G-2 gold conductor, the glazed layer completely covers the conductor patterns as shown in Figure 6(a), causing the glaze surface to become uneven as shown in Table III. With the G-4 gold conductor, it is difficult to form the glazed layer on the conductor patterns because of insufficient wettability as shown in Figure 6(b). The poor edge configuration caused by inadequate wettability (too much or too little) of $\mathrm{PbO}-\mathrm{B}_{2} \mathrm{O}_{3}-\mathrm{SiO}_{2}$ glass with the conductor material makes it difficult to form the thin film at the edge of the glazed layer.

$\mathrm{PbO}-\mathrm{B}_{2} \mathrm{O}_{3}-\mathrm{SiO}_{2}$ glass has adequate wettability with the G-1 gold conductor, so the glazed layer has the well-formed configuration at the edge as shown in Figure 6(c). This is caused by the uniform flow of glazing material on the conductor patterns. Thus, good wettability provides a flat glaze surface even at the edge
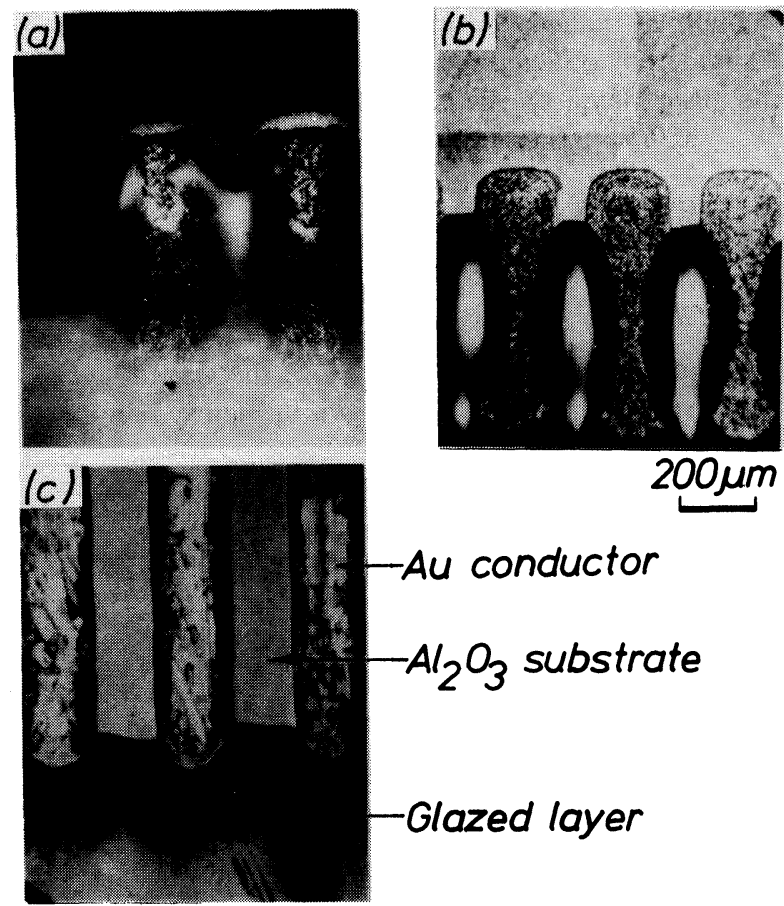

FIGURE 6 Wettability of $\mathrm{PbO}-\mathrm{B}_{2} \mathrm{O}_{3}-\mathrm{SiO}_{2}$ glazing material with a) G-2 conductor, b) G-4 conductor and c) G-1 conductor.

as shown in Table III, showing that thin film patterns can be formed at the edge of the $\mathrm{PbO}-\mathrm{B}_{2} \mathrm{O}_{3}-\mathrm{SiO}_{2}$ glazed layer on G-1 conductor patterns.

Composition analysis results suggest that the G-1 gold conductor contains a very small amount of glass frit, although it is available as fritless paste. The glass frit is thought to give the $\mathrm{PbO}-\mathrm{B}_{2} \mathrm{O}_{3}-\mathrm{SiO}_{2}$ glass moderate wettability with the G-1 gold conductor. The excess wettability observed in the G-2 gold conductor is thought to be due to a larger amount of glass frit than in the G-1 gold conductor. The large amount of glass frit enhances the reaction between the $\mathrm{PbO}-\mathrm{B}_{2} \mathrm{O}_{3}-\mathrm{SiO}_{2}$ glass and the glass frit of the conductor.

Surface roughness of the $\mathrm{PbO}-\mathrm{B}_{2} \mathrm{O}_{3}-\mathrm{SiO}_{2}$ glazed layer formed on the G-1 conductor decreases as firing temperature is increased and shows $0.2 \mu \mathrm{m}$ at $860^{\circ} \mathrm{C}$ as shown in Figure 7. Decrease in surface roughness observed at $860^{\circ} \mathrm{C}$ indicates that the glass begins to flow at this temperature to produce a smoother glaze surface. Sideways flow of the glazed layer becomes significant when it is fired at temperatures above $900^{\circ} \mathrm{C}$, as shown in Figure 8. The sideways flow is caused by excess softening and flowing of the glazing material. The conductor patterns which are formed 


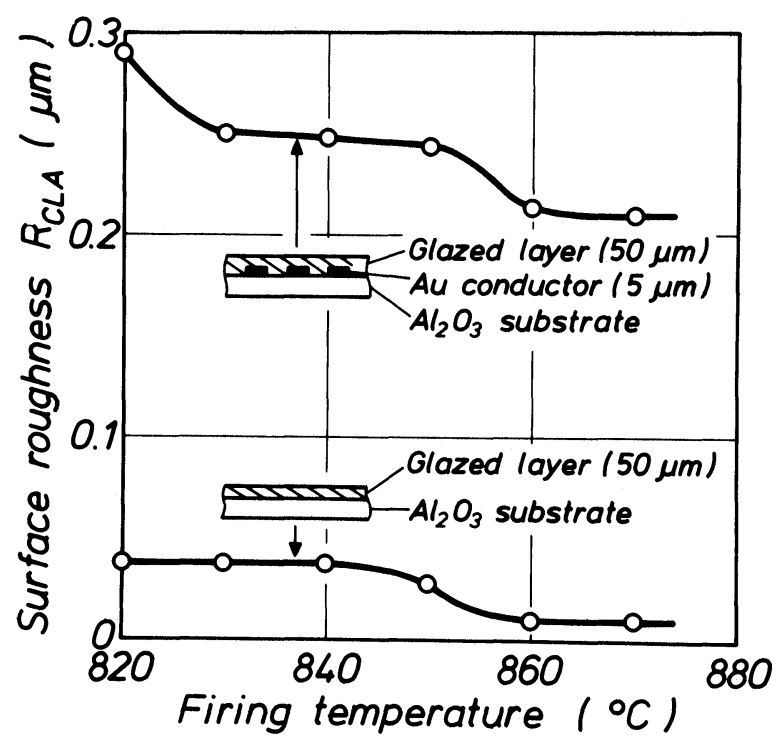

FIGURE 7 Effect of firing temperature on surface roughness of $\mathrm{PbO}-\mathrm{B}_{2} \mathrm{O}_{3} \mathrm{SiO}_{2}$ glazed layer.

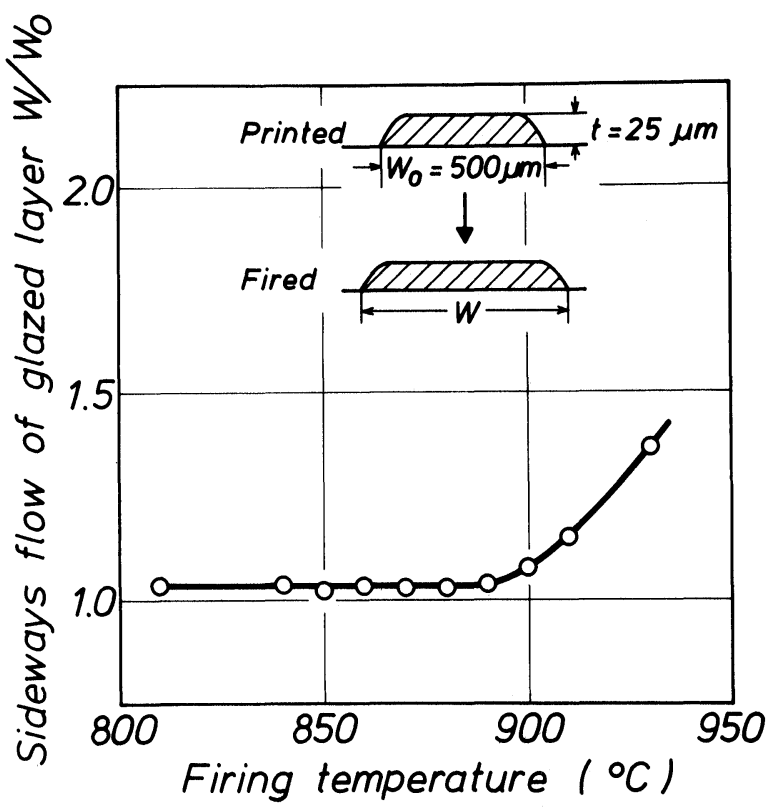

FIGURE 8 Effect of firing temperature on sideways flow of $\mathrm{PbO}-\mathrm{B}_{2} \mathrm{O}_{3}-\mathrm{SiO}_{2}$ glazed layer.

under the glazed layer are covered if glazed layer flows excessively. Thus, $\mathrm{PbO}-\mathrm{B}_{2} \mathrm{O}_{3}-\mathrm{SiO}_{2}$ glass has superior glaze characteristics when fired at temperatures ranging between $860^{\circ} \mathrm{C}$ and $900^{\circ} \mathrm{C}$.

The good results obtained with the $\mathrm{PbO}-\mathrm{B}_{2} \mathrm{O}_{3}-\mathrm{SiO}_{2}$ glass on the G-1 gold conductor lead to their use in the last line visible thermal head.

\section{LAST LINE VISIBLE THERMAL HEAD}

The selective glazed layer of $\mathrm{PbO}-\mathrm{B}_{2} \mathrm{O}_{3}-\mathrm{SiO}_{2}$ glass was formed on gold thick film circuits for the power supply, which were screen printed on the fine grained alumina substrate using G-1 gold conductor paste. The selective glazed layer has a smooth and flat surface even at the edge. Figures 9 to 11 show distributions of edge

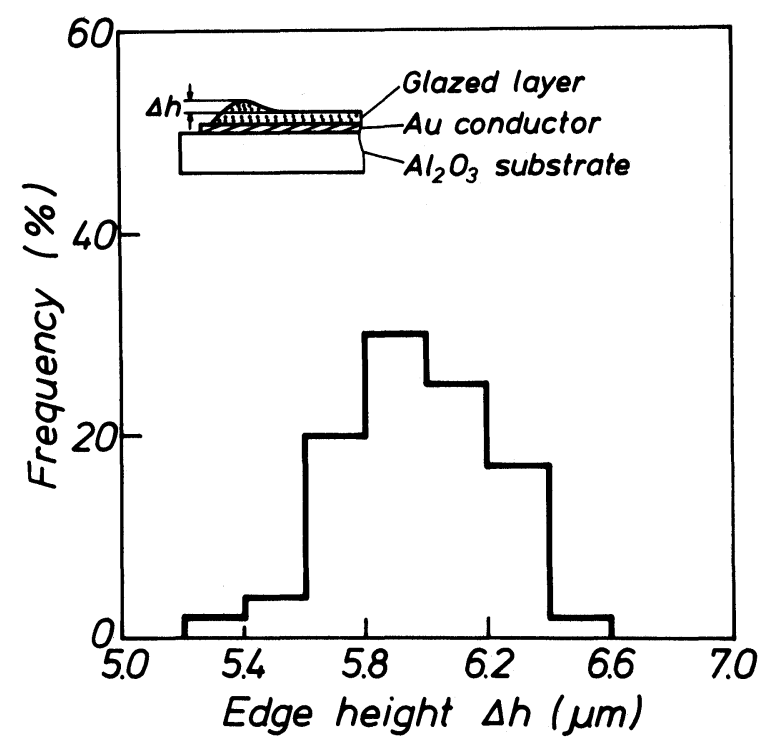

FIGURE 9 Distribution of edge height for $\mathrm{PbO}-\mathrm{B}_{2} \mathrm{O}_{3}-\mathrm{SiO}_{2}$ glazed layer formed on G-1 conducor.

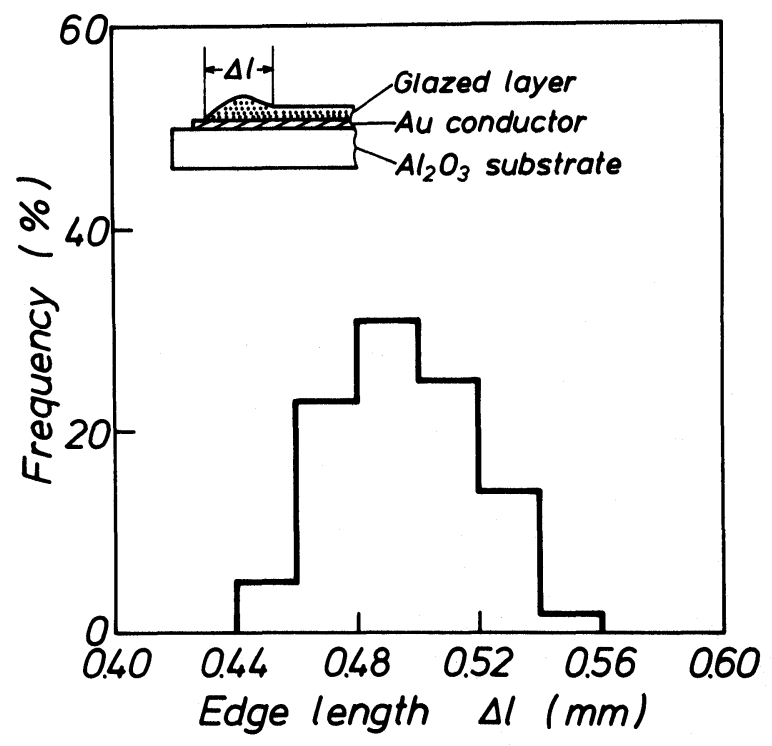

FIGURE 10 Distribution of edge length for $\mathrm{PbO} \cdot \mathrm{B}_{2} \mathrm{O}_{3}-\mathrm{SiO}_{2}$ glazed layer formed on G-1 conductor. 


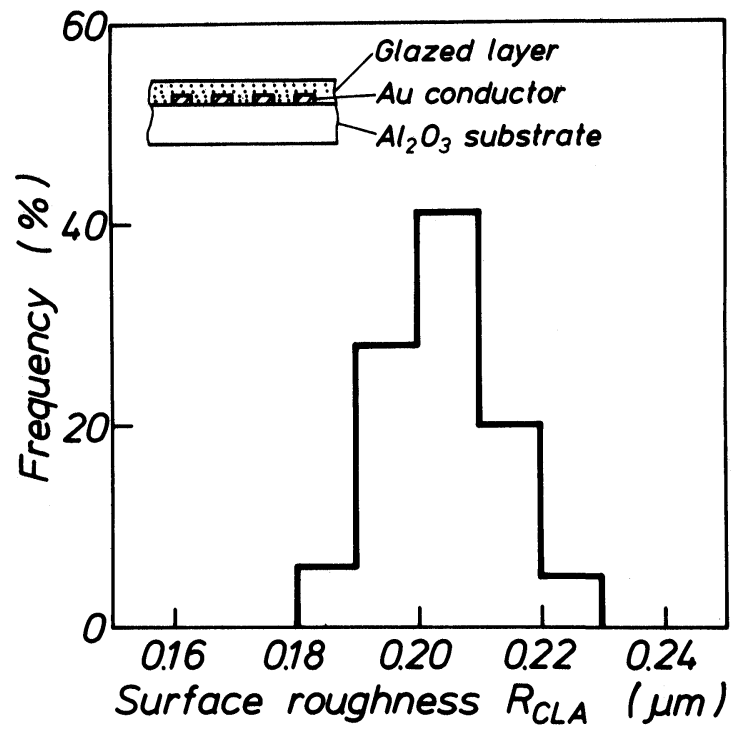

FIGURE 11 Distribution of surface roughness for $\mathrm{PbO}-\mathrm{B}_{2} \mathrm{O}_{3}-\mathrm{SiO}_{2}$ glazed layer formed on G-1 conductor.

height, edge length and surface roughness. $\mathrm{Ta}_{2} \mathrm{~N}$ thin film for the resistive heat sources was formed at the edge of the selective glazed layer. Figure 12 shows the last line visible thermal head and its cross-sectional structure.
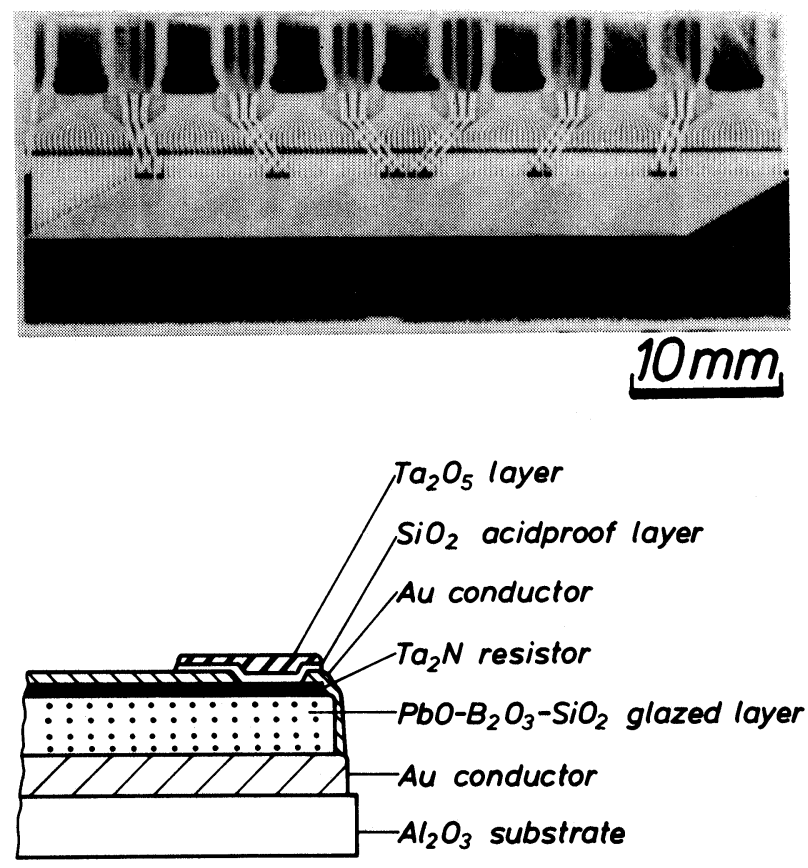

FIGURE 12 Last line visible thermal head and crosssectional structure.
The thermal head shown in Figure 12 can print 20 characters/line at 5 lines/sec with a resolution of 2.7 dots $/ \mathrm{mm}$. The thermal head provides good print quality as shown by the example in Figure 13.

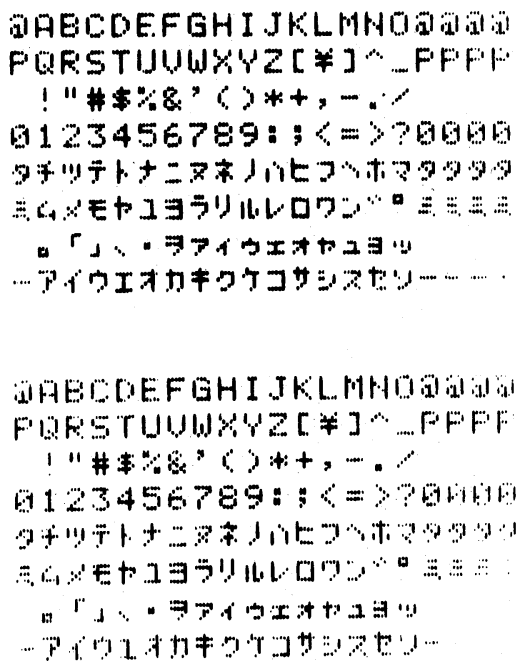

FIGURE 13 Example of printed letters.

\section{SUMMARY}

Selective glaze characteristics were studied using $\mathrm{PbO}-\mathrm{B}_{2} \mathrm{O}_{3}-\mathrm{SiO}_{2}$ and $\mathrm{B}_{2} \mathrm{O}_{3}-\mathrm{SiO}_{2}$ glazing materials in an attempt to produce a last line visible thermal head. Several commercially available gold conductors were screen printed on fine grained alumina substrates. Wettability, levelling characteristics and flatness at the edge of the selective glaze on each gold conductor were examined. Dependence of their characteristics on firing conditions were also examined. A combination of $\mathrm{PbO}-\mathrm{B}_{2} \mathrm{O}_{3}-\mathrm{SiO}_{2}$ glass and fritless gold conductor provides a smooth and flat glaze surface even at the edge. The experimental results show that $\mathrm{PbO}-\mathrm{B}_{2} \mathrm{O}_{3}$ $\mathrm{SiO}_{2}$ glazing material has the suitable characteristics for a last line visible thermal head.

\section{ACKNOWLEDGEMENTS}

The authors would like to thank Drs. H. Sasaki, Y. Nishimura and T. Hara of Fujitsu Limited for their helpful suggestions.

Also, they would like to thank Dr. Z. Henmi and Mr. K. Murakawa of Fujitsu Laboratories Ltd. for their encouragement. 


\section{REFERENCES}

1. K. Niwa, J. Nakamura, K. Murakawa and M. Nakamura, "New Alumina Substrate for Hybrid Integrated Circuits", IEEE Trans. on Parts, Hybrids and Packaging, Vol. PHP-10, No. 4, 262-266 (1974).
2. K. Niwa and K. Murakawa, "New Alumina Substrate for Microelectronics", Electrocomponent Science and Technology, 2, 115-119 (1975). 

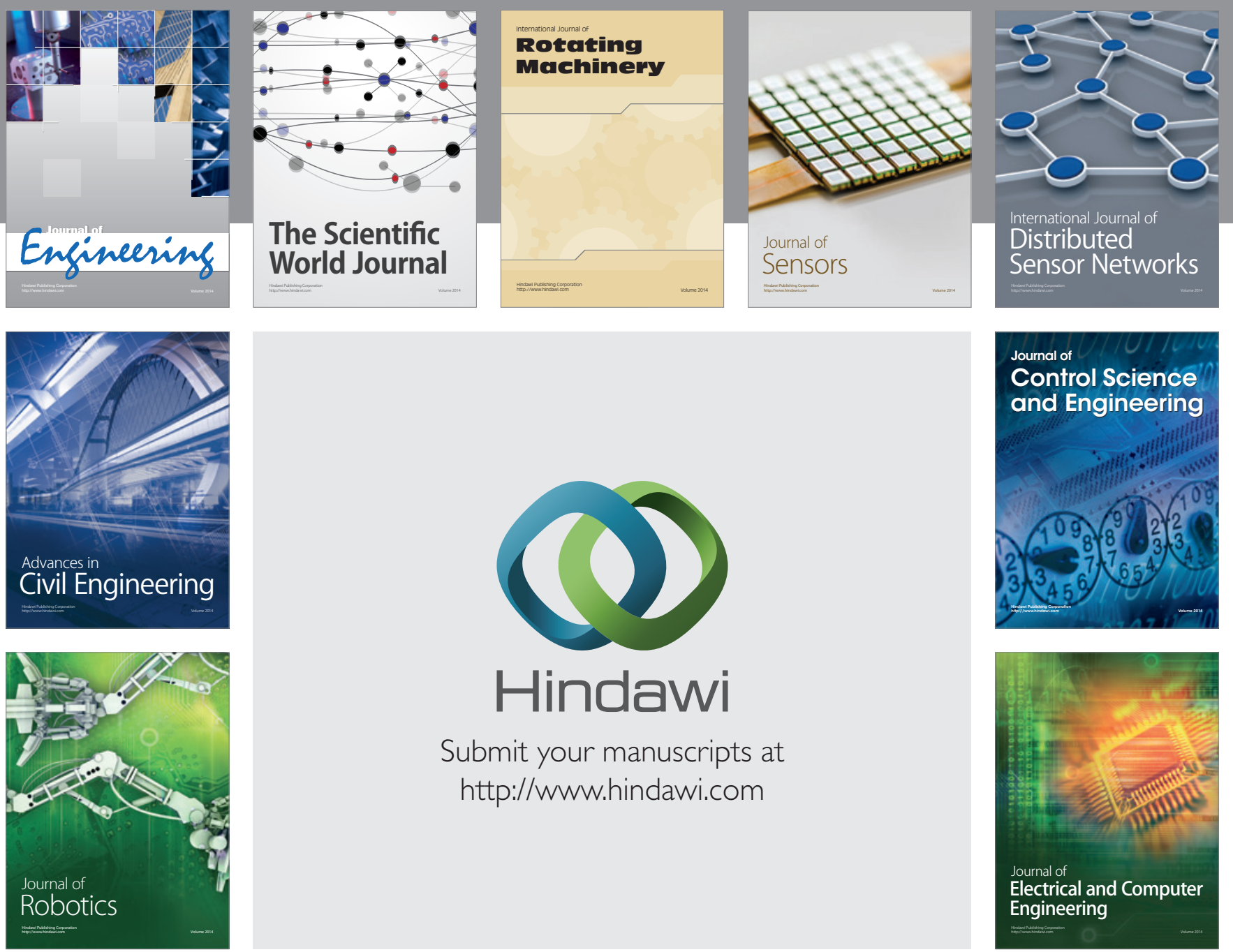

Submit your manuscripts at

http://www.hindawi.com
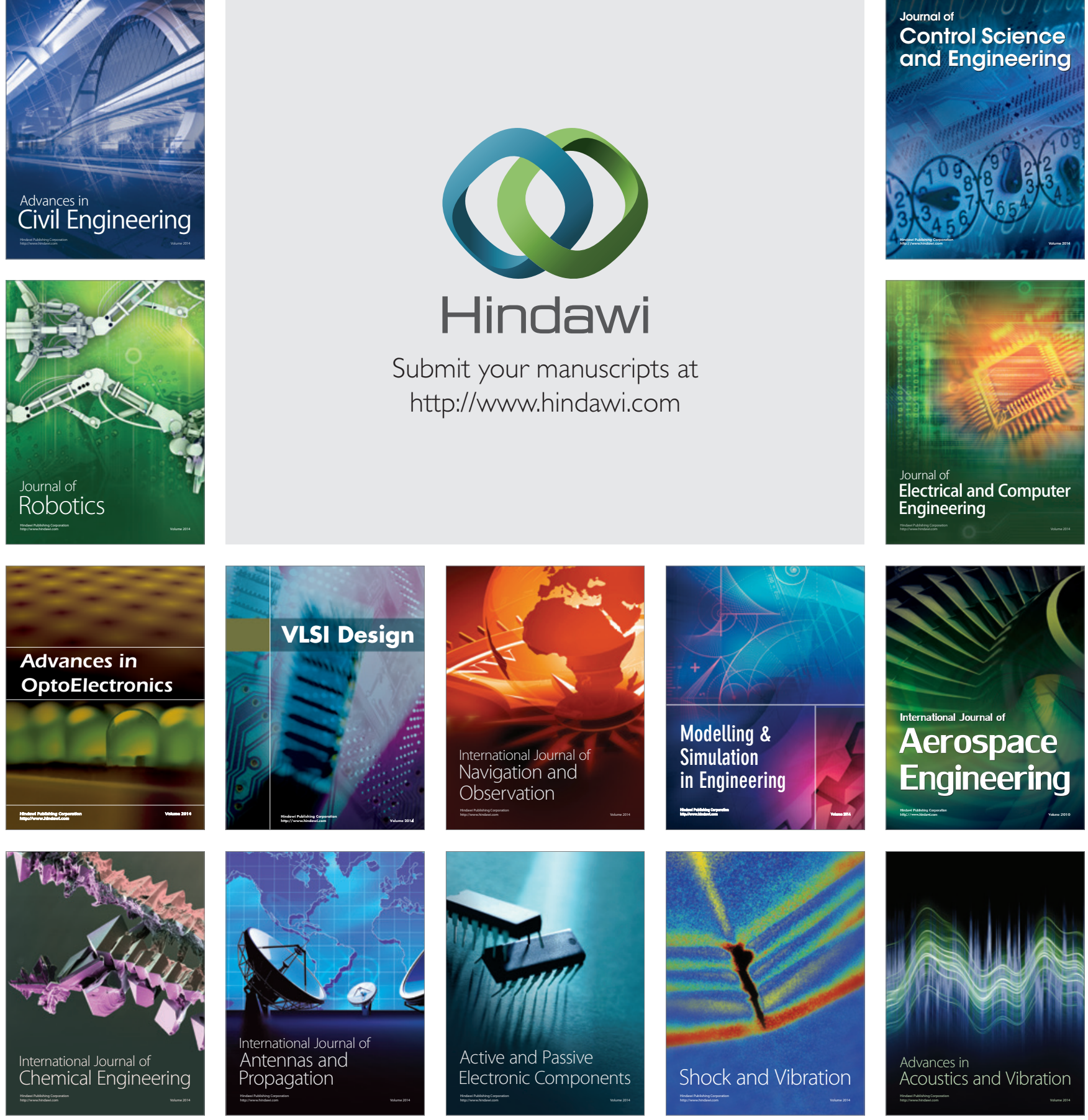